\title{
Global and Local Challenges to Refugee Protection ${ }^{1}$
}

Silas W. Allard ${ }^{2}$

\section{INTRODUCTION}

On October 12, 2017, the United States Attorney General, Jeff Sessions, took a short trip from Pennsylvania Avenue across the Potomac to Falls Church, Virginia. The Attorney General went to Falls Church to address personnel of the Executive Office of Immigration Review (EOIR), the agency that administers the United States' immigration courts. The Attorney General's chosen topic for the day was "the fraud and abuse in our asylum system." 3 "Over the years," the Attorney General argued, "Congress has rationally passed legislation designed to create an efficient and fair procedure to properly admit persons and expedite the removal of aliens who enter the United States illegally." 4 The Attorney General is referring here to the "expedited removal" procedures that Congress created in the Illegal Immigration Reform and Immigrant Responsibility Act of 1996. ${ }^{5}$ Expedited removal gives the Department of Homeland Security ${ }^{6}$ the power to deport, without a hearing, any person who was not admitted to the United States and who cannot prove continuous presence for the prior two years. The Department of Homeland Security currently exercises a narrower expedited removal authority pursuant to the Department's prosecutorial discretion. Only individuals apprehended within two weeks of entry and within 100 miles of a land border are subject to expedited removal, per Department regulations. ${ }^{7}$

In his remarks at immigration court headquarters, the Attorney General went on to say that, "over the years, smart attorneys have exploited loopholes in the law, court rulings, and lack of resources to substantially undermine the intent of Congress. They have been able to do so because this expedited removal contains an exception. For aliens

${ }^{1}$ This is a revised version of the lecture delivered to the International Association of Law Libraries' 36th Annual Course on International Law and Legal Information, Civil Rights, Human Rights, and Other Critical Issues in U.S. Law, Atlanta, Georgia, October 24, 2017.

2 (C) Silas W. Allard 2018. Associate Director and Harold J. Berman Fellow in Law and Religion, Center for the Study of Law and Religion, Emory University, Atlanta, Georgia, USA.

3 Jeff Sessions, "Remarks to the Executive Office of Immigration Review" (Falls Church, VA, October 12, 2017), https:// www.justice.gov/opa/speech/attorney-general-jeff-sessions-delivers-remarks-executive-office-immigration-review.

4 Sessions, "Remarks to the Executive Office of Immigration Review" (emphasis added).

5 Illegal Immigration Reform and Immigrant Responsibility Act, Pub. L. No. 104-208, div. C, § 302,110 Stat. 3009-546, 3009-579 (1996) (codified at 8 U.S.C. § 1225).

6 The Illegal Immigration Reform and Immigrant Responsibility Act refers to the Attorney General as the office with authority to set the parameters of expedited removal; however, that authority was transferred to the Secretary of the Department of Homeland Security with the creation of DHS in 2002. See Designating Aliens for Expedited Removal, 69 Fed. Reg. 48,877, 48,878 (August 11, 2004).

${ }^{7}$ Designating Aliens for Expedited Removal, 69 Fed. Reg. at 48879. A memorandum leaked in July 2017 indicated that the Trump Administration was considering new regulations that would remove the geographical limitation and expand the temporal limitation to ninety days. Abigail Hauslohner and David Nakamura, "In Memo, Trump Administration Weighs Expanding the Expedited Deportation Powers of DHS," Washington Post, July 14, 2017, sec. National Security, https://www.washingtonpost. com/world/national-security/in-memo-trump-administration-weighs-expanding-the-expedited-deportation-powers-of-dhs/2017/ 07/14/ce5f16b4-68ba-11e7-9928-22d00a47778f_story.html. At the time of submission, the Trump administration had not changed the regulations on expedited removal. 
who have an actual, legitimate fear of returning to their homeland, he or she can seek asylum." ${ }^{8}$ Here, the Attorney General is referencing the credible fear review process. If an individual in expedited removal proceedings "indicates either an intention to apply for asylum ... or expresses a fear of persecution," then the individual must be referred to an asylum officer for a credible fear interview. ${ }^{9}$ If the asylum officer determines that the individual has a credible fear of persecution, then he or she will have the opportunity to seek asylum in an adversarial proceeding before an immigration judge. If the asylum officer does not find the individual's fear credible, that finding can also be appealed to an immigration judge for review. ${ }^{10}$

Credible fear review is necessary to meet the United States' obligations under international law. As a state party to the Refugee Convention, the US is under an obligation of non-refoulement, meaning that it cannot return a person to a situation of persecution. ${ }^{11}$ Because expedited removal permits removal without a hearing, some effective mechanism must exist to prevent the United States from deporting individuals back to situations of persecution.

The Attorney General, however, views the credible fear review as a process subject to rampant abuse. "This is a compassionate country," the Attorney General said in his remarks to EOIR, "and lawfully admits more immigrants than any country in the world. But we must recognize that our generous system is being terribly abused. As one immigration judge recently told me about the credible fear process, 'any adjudicatory system with a grant rate of nearly 90 percent is inherently flawed." 12 If the credible fear review process is subject to a pattern of abuse, then the individuals who are being given an opportunity to have their asylum claims heard must not have legitimate asylum claims. As the Attorney General notes, "aliens who have an actual, legitimate fear of returning to their homeland ... can seek asylum." 13 In other words, the Attorney General has predetermined that a large portion of these claims are illegitimate before they are reviewed.

A claim for asylum could be illegitimate in one of two ways: (1) it could be factually illegitimate, meaning that the claimant has not experienced persecution, and has no belief that he or she will experience persecution in the future, in other words, the claimant does not actually fear return to his or her country, or (2) it could be legally illegitimate, meaning that the fear the person has is not legally sufficient for asylum. To substantiate his claim of illegitimacy, the Attorney General argued to the immigration judges that "Our asylum laws are meant to protect those who because of characteristics like their race, religion, nationality, or political opinions cannot find protection in their home countries. They were never intended to provide asylum to all those who fear generalized violence, crime, personal vendettas, or a lack of job prospects. Yet, vague, insubstantial, and subjective claims have swamped our system." 14 The Attorney General is making a claim of legal illegitimacy here, (although his rhetoric of fraud and abuse imputes factual illegitimacy as well). To make his claim of legal illegitimacy, the Attorney General is pointing to what is called the "nexus requirement" in asylum law. The definition of a refugee in both international law and domestic law requires that the individual be fleeing persecution and that such persecution be "on account of" one of

${ }^{8}$ Sessions, "Remarks to the Executive Office of Immigration Review."

98 U.S.C. $\S 1225(\mathrm{~b})(1)(\mathrm{A})(\mathrm{ii})$; see also 8 C.F.R. 1235.3(b)(4).

${ }^{10}$ For a succinct summary of the credible fear review process, see Sara Campos and Joan Friedland, Mexican and Central American Asylum and Credible Fear Claims: Background and Context, May 2014, https://www.americanimmigrationcouncil. org/research/mexican-and-central-american-asylum-and-credible-fear-claims-background-and-context.

${ }^{11}$ Convention Relating to the Status of Refugees, art. 33, July 28, 1951, 189 U.N.T.S. 137 (hereinafter 1951 Refugee Convention). The US assumed the obligations of the 1951 Refugee Convention when it ratified the 1967 Refugee Protocol. Protocol Relating to the Status of Refugees, art. 1(1), Jan. 31, 1967, 19 U.S.T. 6233, 606 U.N.T.S 267 (hereinafter 1967 Refugee Protocol). The US subsequently domesticated its international obligations under the Refugee Convention with the 1980 Refugee Act. Refugee Act of 1980, Pub. L. No. 96-212, 94 Stat. 102 (1980); see also Matthew J. Gibney, The Ethics and Politics of Asylum: Liberal Democracy and the Response to Refugees (Cambridge: Cambridge University Press, 2004), 161 ("The incorporation of the Refugee Convention's Protocol into the 1980 Refugee Act bound the US to an obligation not to refoule any person at or within its borders with a legitimate claim to refugee status. While this is not an obligation to grant asylum per se, the difficulties of gaining protection for refugees in other countries usually makes it a de facto duty."). In the text, unless otherwise indicated, I use "Refugee Convention" to refer to the 1951 Refugee Convention as modified by the 1967 Refugee Protocol.

${ }^{12}$ Sessions, "Remarks to the Executive Office of Immigration Review."

${ }^{13}$ Sessions.

${ }^{14}$ Sessions. 
five factors. ${ }^{15}$ The Attorney General lists four of these five factors: race, religion, nationality, and political opinion. He pointedly omits the fifth: membership in a particular social group.

The particular social group factor has been developed as a ground of asylum for women fleeing domestic violence and LGBTQ persons fleeing persecution based on their sexual orientation, among others. ${ }^{16}$ The Attorney General's simultaneous omission of a particular social group as a potential nexus factor, and his pointed exclusion from protection for those "who fear generalized violence, crime, [and] personal vendettas," are both clearly aimed at Central American asylum seekers from El Salvador, Honduras, and Guatemala, many of whom have claims based in wide-spread gang activity and other forms of violence. ${ }^{17}$ The Attorney General is arguing that the claims of Central American asylum seekers should largely be foreclosed as not cognizable under the laws of the United States; in the act of seeking asylum they are committing a fraud on the United States. The Attorney General pre-judges en masse what is an individualized determination under both international and domestic law. In this regard he attempts to inhibit what Andrew Schoenholtz has described as the evolutionary potential of the Refugee Convention to address the changing nature of displacement, ${ }^{18}$ and this perspective on asylum has real implications at the level of local adjudication in jurisdictions such as Atlanta, Georgia. But, the Attorney General's argument is also grounded in an understanding of asylum that proceeds from the Refugee Convention. As Alexander Betts has written:

Given the era and geographical context in which the modern refugee regime was created (post-Second World War Europe), "refugee"- and hence who qualified for access to asylum — was given a very specific meaning. The definition of a refugee was mainly limited to people fleeing targeted persecution by their own governments. Yet after the creation of the refugee regime in the $1950 \mathrm{~s}$, the circumstances that shape flight changed. New drivers of cross-border displacement emerged ... . Factors such as generalized violence, environmental change, and food insecurity - and their interaction - underpin a significant and growing proportion of cross-border displacement in many parts of the world. ... This opens up the question of who should be entitled to cross an international border on the grounds of human rights. ${ }^{19}$

It is to these global challenges that I turn first.

\section{Global Challenges}

In 1951, the Convention Relating to the Status of Refugees was opened for signature in Geneva. This new treaty, in the spirit of the 1945 Charter of the United Nations and the 1948 Universal Declaration of Human Rights, ${ }^{20}$ was an attempt to address the aftermath of the Second World War in a comprehensive and cooperative mode. There had been other efforts under international law to address the issue of refugees prior to 1951, but these efforts addressed particular displacements on an ad hoc basis. ${ }^{21}$ As Einarsen writes: "This method, to tie protection to particular national groups in ad hoc instruments as new refugee situations arose, would be characteristic for the League

151951 Refugee Convention, art. 1(A)(2); 8 U.S.C. $§ 1101(\mathrm{a})(42)(\mathrm{A})$.

${ }^{16}$ Matter of A-R-C-G, 26 I\&N Dec. 388, 388-89 (BIA 2014) (holding that "married women in Guatemala who are unable to leave their relationship" was a legitimate social group for purposes of seeking asylum); Matter of Toboso-Alfonso, 20 I\&N Dec. 819, 822 (BIA 1994) (holding that homosexuality could be a legitimate social group for purposes of seeking asylum). For a detailed analysis of particular social group, see Lisa Frydman and Neha Desai, "Beacon of Hope or Failure of Protection? U.S. Treatment of Asylum Claims Based on Persecution by Organized Gangs," Immigration Briefings, October 2012. https://cgrs. uchastings.edu/sites/default/files/October\%202012\%20Immigration\%20Briefings.pdf.

${ }^{17}$ For an analysis of the challenges facing gang-based asylum claims, see Frydman and Desai, "Beacon of Hope or Failure of Protection? U.S. Treatment of Asylum Claims Based on Persecution by Organized Gangs."

18 Andrew I. Schoenholtz, "The New Refugees and the Old Treaty: Persecutors and Persecuted in the Twenty-First Century," Chicago Journal of International Law 16 (2015-2016): 81-126.

19 Alexander Betts, Survival Migration: Failed Governance and the Crisis of Displacement (Ithaca, NY: Cornell University Press, 2013), 2.

${ }^{20} 1951$ Refugee Convention, preamble ("Considering that the Charter of the United Nations and the Universal Declaration of Human Rights approved on 10 December 1948 by the General Assembly have affirmed the principle that human beings shall enjoy fundamental rights and freedoms without discrimination ....").

${ }^{21}$ For a good discussion of the pre-1951 history of refugee protection, see Terje Einarsen, "Part One Background, Drafting History of the 1951 Convention and the 1967 Protocol," in The 1951 Convention Relating to the Status of Refugees and Its 1967 Protocol: A Commentary, ed. Andreas Zimmermann, Felix Machts, and Jonas Dörschner, Oxford Commentaries on 
of Nations' approach to the refugee problem throughout its years. With this type of definition 'by categories', interpretation was simple, but protection of new groups uncertain." 22 The 1951 Refugee Convention, by contrast, established a general definition. This general definition also shifted the analysis from groups to individuals. ${ }^{23}$ Unlike the UN Charter and the Universal Declaration, however, the 1951 Refugee Convention was principally reactive, rather than forward looking. Thus, in Article 1 the Convention limited the definition to those persons impacted by events "occurring before 1 January 1951." 24 Furthermore, the 1951 Convention permitted states parties to the Convention to declare that "events occurring before 1 January 1951" meant "events occurring in Europe before 1 January 1951." 25 These provisions came to be known as the temporal and geographic limitations.

The temporal and geographic limitations were removed by the 1967 Protocol to the Convention. ${ }^{26}$ Global turmoil did not end with the Second World War. Cold War conflicts and decolonization movements resulted in new displacements that were outside the scope of the 1951 Refugee Convention. With the removal of the temporal and geographic limitations, the Refugee Convention could address the reality of ongoing and widespread displacement, particularly under new authoritarian regimes around the world. ${ }^{27}$

But, the world and the nature of displacement have changed again since 1967. According to Betts, "While there has been a decline in the kinds of repressive or authoritarian states of the Cold War era, there has been an increase in the number of fragile states .... This trend means that fewer people are fleeing persecution resulting from the acts of states while more are fleeing human rights deprivations resulting from the omissions of weak states that are unable or unwilling to ensure fundamental rights." ${ }^{28}$ Andrew Schoenholtz has described this development with more particularity through his idea of "ungoverned spaces," "where state control is absent, weak, or contested." In these "ungoverned spaces," "[n]on-state actors, such as Hezbollah in Lebanon, FARC in Colombia, and Mara Salvatrucha [MS-13] in El Salvador, have 'provided state-like functions for extended periods of time in recent years." 29 While these non-state actors have provided state-like functions, they have also engaged in the kind of violence and deprivation of rights that had been, at least in the eyes of the Refugee Convention, characteristic of states. Sometimes non-state actor persecution intersects with a protected category: when, for example, ISIS targets Yazidis for religious persecution. ${ }^{30}$ But, often it does not. The Honduran shop owner extorted for protection money; the El Salvadoran teen whose family is threatened because he won't join the gang. Smart attorneys, in Attorney General Sessions words (although, I don't think he was paying a compliment), have had limited success with claims under particular social group based on, for example, combinations of family ties, geography, and gang threats, and others have begun to argue that, because gangs operate as quasi-state actors, opposition to the gang is effectively a political opinion that draws persecution in analogously to the persecution of opposition political parties in authoritarian regimes. ${ }^{31}$ But, despite such efforts, lodging these kinds of claims remains a significant challenge because they are not native to the context of the Refugee Convention.

International Law (Oxford: Oxford University Press, 2011), http://opil.ouplaw.com.proxy.library.emory.edu/view/10.1093/ actrade/9780199542512.001.0001/actrade-9780199542512-chapter-2.

${ }^{22}$ Einarsen, para. 9. See also Guy S. Goodwin-Gill and Jane McAdams, The Refugee in International Law, 3rd ed. (Oxford: Oxford University Press, 2007), 16 ("In treaties and arrangements concluded under the auspices of the League of Nations, a group or category approach was adopted. That someone was (a) outside their country of origin and (b) without the protection of the government of that State, were sufficient and necessary conditions."). Goodwin-Gill and McAdams view these earlier, post-World War I definitions as based in "flexible or open groups and categories," and they see a move after World War II to "more closed and legalistic" definitions that culminated with the 1951 Convention. Goodwin-Gill and McAdams, 19.

${ }^{23}$ Schoenholtz, "The New Refugees and the Old Treaty," 107-08.

${ }^{24} 1951$ Refugee Convention, art. 1(A)(2).

${ }^{25} 1951$ Refugee Convention, art. 1(B)(1).

${ }^{26} 1967$ Refugee Protocol, art. 1(2).

${ }^{27}$ Schoenholtz, "The New Refugees and the Old Treaty," 85-86.

${ }^{28}$ Betts, Survival Migration: Failed Governance and the Crisis of Displacement, 2.

${ }^{29}$ Schoenholtz, "The New Refugees and the Old Treaty," 93.

${ }^{30}$ Avi Asher-Schapiro, "Who Are the Yazidis, the Ancient, Persecuted Religious Minority Struggling to Survive in Iraq?" National Geographic News (August 11, 2014), https://news.nationalgeographic.com/news/2014/08/140809-iraq-yazidis-minority-isil-religion-history/.

${ }^{31}$ Frydman and Desai, "Beacon of Hope or Failure of Protection? U.S. Treatment of Asylum Claims Based on Persecution by Organized Gangs.” 
The global challenges are in part the limited scope of the Refugee Convention and subsequent exclusion of some forms of displacement. ${ }^{32}$ But a significant part of the challenge is also how "mixed migration" and "mixed motivations" creates skepticism about the displaced under a narrow definition of refugee. As Fillipo Grandi, the UN High Commissioner for Refugees, noted in a recent interview with National Public Radio: "increasingly, the causes of flight are all intertwined. Conflict gets linked up with poverty because conflict produces poverty. And poverty produces conflict." Grandi went on to provide the example of Nigeria:

What I'm saying is that people that flee conflict often are also very poor people. And then you have climatic factor. Think of northern Nigeria. This is a very clear example in which the combination of poverty, lack of education, underdevelopment, plus climatic factor has favored the birth of a terrorist movement, which has been the direct cause of the displacement of millions of people. But you should not lose sight of the interlinkages between the causes. ${ }^{33}$

Put succinctly by Erika Feller, former head of International Protection at UNHCR, "Mixed population flows do not always lend themselves to management completely within the Convention framework." 34 But this indeterminacy also breeds opportunity for states to decry "fraud" and "abuse" of the asylum system by people who are fleeing violence and persecution by another name. As Schoenholtz has argued "State Parties have tried for some time to minimize [the Refugee Conventions] relevance to today's forced migrants." 35 The structural, definitional challenges of the Convention facilitate this effort of minimization, and we can see the process at work when we examine the local challenges facing asylum seekers in jurisdictions throughout the United States, and particularly here in Georgia.

\section{Local Challenges}

For fiscal year 2016 (the most recent year for which we have data), the nation-wide grant rate for asylum in the United States was $43 \% .{ }^{36}$ This average stands in stark comparison to the asylum grant rates in Georgia. Georgia is home to two immigration courts: the Atlanta immigration court and the court at Stewart Detention Center in Lumpkin, Georgia. In FY2016, the asylum grant rate for the Atlanta immigration court was 2\%; the grant rate at Stewart Detention Center was $7 \% .^{37}$

This is not a recent phenomenon. In FY2000, the overall grant rate for asylum was $36 \%, 38$ and the grant rate in Atlanta was 3\%. ${ }^{39}$ During the period FY2000-FY2016, the Atlanta immigration court's grant rate peaked at 25\% (FY2009), but even at its highest point, immigration judges in Atlanta granted just over half as many asylum requests as the average judge. Asylum grant rates at Stewart Detention Center have not yet exceeded 7\%.

There is anecdotal evidence that the disparity in asylum grant rates is connected to a perspective among immigration judges in Georgia jurisdictions that there is a greater prevalence of meritless cases in those jurisdictions. In 2001 the Los Angeles Times published an article based on analysis of immigration judge decisions. The article

${ }^{32}$ And, it is worth noting here, although I don't have time to pursue it, that climate-change displacement is also a growing challenge to the Refugee Convention. For a discussion of climate change and forced displacement, see "Disasters and Displacement in a Changing Climate," special issue, Forced Migration Review, no. 49 (2015), http://www.fmreview.org/climatechange-disasters/fernandez.html.

33 "U.N. Commissioner Wants U.S. to Show Leadership on Refugee Crisis,” NPR, October 23, 2017, http://www.npr.org/ 2017/10/23/559454562/u-n-commissioner-wants-u-s-to-show-leadership-on-refugee-crisis (transcript of radio broadcast).

${ }^{34}$ Erika Feller, "The Refugee Convention at Fifty Forum: Refugees," Georgetown Journal of International Affairs 3 (2002): 8 .

${ }^{35}$ Schoenholtz, "The New Refugees and the Old Treaty," 83.

${ }^{36}$ U.S. Department of Justice, Executive Office of Immigration Review, FY 2016 Statistics Yearbook (Falls Church, VA, March 2017), K12, fig. 16, https://www.justice.gov/eoir/page/file/fysb16/download. The Grant rate is down over the past five years from 56\% in FY 2012.

${ }^{37}$ Executive Office of Immigration Review, FY 2016 Statistics Yearbook, K13, table 12. The court at Stewart Detention Center heard its first asylum cases in FY2010. U.S. Department of Justice, Executive Office of Immigration Review, $F Y$ 2010, Statistics Yearbook (Falls Church, VA, January 2011), K6, table 8, http://www.justice.gov/eoir/statspub/syb2000main. htm.

${ }^{38}$ U.S. Department of Justice, Executive Office of Immigration Review, FY 2000 Statistics Yearbook (Falls Church, VA, January 2001), O2, table 15, https://www.justice.gov/sites/default/files/eoir/legacy/2001/05/09/SYB2000Final.pdf.

${ }^{39}$ Executive Office of Immigration Review, O3, table 16. 
highlighted an Atlanta immigration judge who had approved 0 asylum requests from 807 Guatemalans who appeared before him over the course of six years, and who had approved only " 80 requests of 2,398 filed by immigrants from other nations," in the same time period. In a rare response provided through a court spokesperson, the judge argued that Atlanta "does "not get the kind of cases that are easily granted." 40

In a 2016 article in Vice Magazine, a local non-profit attorney "suggested local lawyers might be hesitant to take asylum cases because they expect to be stonewalled by an immigration judge. If they do invest in an asylum case, he says, they should prepare to take it to the Board of Immigration Appeals or, if that fails, to the US Court of Appeals for the Eleventh Circuit." ${ }^{11}$ In a 2016 Huffington Post article, Elise Foley reports another attorney's account that "judges have told her they think granting asylum in certain instances would open the floodgates and make them bound to grant relief more often in general, going against an office culture of high skepticism of those claims." 42

The Southern Poverty Law Center, in collaboration with Prof. Hallie Ludsin's human rights practicum at Emory Law School, conducted court observation at the Atlanta immigration court during the fall of 2016. Based on information collected by students during their court watching, SPLC published a letter to then EOIR Director Juan Osuna detailing concerns about the operation of the Atlanta immigration court. In one of its findings, SPLC observed that "Immigration Judges made prejudicial statements and expressed significant disinterest or even hostility towards respondents in their courts." 43 Of particular interest for our discussion, the court observers reported examples of prejudice in its most literal sense - a pre-judging-against the asylum claims before the court. In one example, observers reported a judge observing in court that "individuals before [him] were economic migrants and that they do not pay taxes." 44 The judge then "concluded the hearing by stating that the credible fear standard is not a proper test for review of asylum seekers, wholly disregarding the established legal standard for such cases," and "[i]n a private conversation after this case, [the judge] told the observer that the cases that come before him involve individuals 'trying to scam the system' and that none of them want to be citizens." 45 The Attorney General's broad-brush of illegitimacy appears to also exist at the level of the trial judge.

The rise in claims of asylum by migrants from Central America seems to be exacerbating the perception that illegitimate claims are prevalent. The Washington Post reported in 2016 that "[o]ver the past five years, the asylum grant rate - at 48 percent nationally, according to government data-has risen in New York from 76 percent to 84 percent, reflecting a more generous attitude toward not just Central Americans but also other immigrants. In Atlanta, however, it has fallen from 23 percent to 2 percent." 46 The perception of the Central American claims as meritless, or even fraudulent, appears to be driving a trend toward denial, even in other kinds of cases. As another example, the Post noted the experience of one local attorney, who could no longer bond her clients out of immigration detention, which significantly increases their overall chances of success ${ }^{47}$ : "For years, judges had granted bond without much thought, but that began to change in 2014, as Central Americans ... entered the system. The soft-spoken Guatemalan

${ }^{40}$ Lisa Getter, "Few Applicants Succeed in Immigration Courts," Los Angeles Times, April 15, 2001, http://articles.latimes. com/2001/apr/15/news/mn-51336.

41 Ted Hesson, “Why It's Almost Impossible to Get Asylum in Atlanta,” Vice, June 8, 2016, https://www.vice.com/en_us/ article/bn38x5/why-its-almost-impossible-to-get-asylum-in-atlanta.

42 Elise Foley, "Here's Why Atlanta Is One of the Worst Places to Be an Undocumented Immigrant," Huffington Post, May 25, 2016, sec. Politics, https://www.huffingtonpost.com/entry/deportation-raids-immigration-courts_us_574378d9e4b0613b512b0f37.

${ }^{43}$ Hallie Ludsin, Lisa Graybill, and Eunice Cho, "Letter to Juan P. Osuna, Director, Executive Office of Immigration Review, 'Observations of Atlanta Immigration Court,'” March 2, 2017, https://www.splcenter.org/sites/default/files/2017-atl_ complaint_letter_final.pdf.

${ }^{44}$ Ludsin, Graybill, and Cho.

${ }^{45}$ Ludsin, Graybill, and Cho.

46 Chico Harlan, "In an Immigration Court That Nearly Always Says No, a Lawyer's Spirit Is Broken," Washington Post, October 11, 2016, sec. Business, https:/www.washingtonpost.com/business/economy/in-an-immigration-court-that-nearly-alwayssays-no-a-lawyers-spirit-is-broken/2016/10/11/05f43a8e-8eee-11e6-a6a3-d50061aa9fae_story.html (emphasis added).

${ }^{47}$ A 2011 study out of New York indicated that the two factors that most impact a person's likelihood of success in removal proceedings are whether the person is detained (detention diminishes the likelihood of success) and whether the person is represented (representation increases the likelihood of success). Peter L. Markowitz et al., Accessing Justice: The Availability and Adequacy of Counsel in Immigration Proceedings, December 2011, 3. These two factors are likely correlated. See Ingrid V. Eagly and Steven Shafer, "A National Study of Access to Counsel in Immigration Court," University of Pennsylvania Law Review 164, no. 1 (2015): 50. 
whose land had been seized under threat. Denied. A Salvadoran forced by gang members to perform oral sex at knifepoint, now with a scar across his face. Denied. An anti-drug detective who defected from a unit in which other men were helping gangs. Denied." 48 As difficult cases at the edge of the legal definition of refugee proliferate, it appears that the tendency is not to carefully consider these new claims and the possibility that they represent legitimate, if novel, grounds for asylum; rather, the tendency is to police the legal boundaries of asylum more rigorously to the detriment of all claims.

This is, to be certain, anecdotal evidence. More study is needed to understand what is happening in immigration courts. Furthermore, the evidence presented here does not, nor is it intended to prove or suggest that immigration judges are hard-hearted or malicious. As another attorney quoted in Foley's article for the Washington Post argued: "I hope people's eyes are opened and that people understand that a lack of due process is not necessarily the result of evil actions,' ... . 'Sometimes the lack of due process is because the systems are broken. The system could be full of good people - it's just not working." 49 There are numerous factors that contribute to this system not working, including the overuse of detention, especially in remote and difficult to access parts of the country making legal representation difficult or impossible; underfunding of EOIR, resulting in extremely high caseloads for judges; and many unscrupulous attorneys who are unprepared or uninterested in providing their clients and the court with skilled representation. But, I would argue, that part of the problem is also the systemic, definitional limitations of the international law, which are exploited at the level of national politics, by figures like the Attorney General, to constrain access to asylum, which provides a context for immigration judges to see their role as defenders of a narrow asylum policy, rather than adjudicators of individual claims.

\section{Conclusion: A Human Centered Refugee Policy}

Let me conclude by expanding on how I think these global and local challenges are connected, and by offering an initial suggestion for what I believe is necessary to guarantee a robust system of protection for those fleeing persecution, violence, and deprivation.

First, both the Refugee Convention and the Atlanta case-study reveal a prioritization of legal categories. There are refugees and other types of migrants; claims with merit and claims without merit; legitimate and illegitimate asylum seekers. Like any good legal distinction, these categories are based on a set of criteria, but those criteria have become legalistic in the pejorative sense of the term. Or, to invoke a common law distinction, refugee law struggles with a sense of equity. In this regard, the global challenge is the local challenge: a legalistic reading of the refugee convention is the possibility of narrowly construed grants of asylum. As the nature of flight from harm changes across the globe, the Refugee Convention is interpreted as a basis for policies that exclude some or many of those fleeing harm. When Attorney General Sessions attacks the credible fear review process as a site of abuse he is manifesting this tendency. When immigration judges view their job as turning the tide of meritless claims, rather than adjudicating each claim on its merits, they are manifesting this tendency.

My argument to you today is that we need to center the human, not the legal category, in our refugee policy globally and locally. I take my inspiration here from my friend and colleague Abdullahi An-Na'im, who you will have the pleasure of hearing during his keynote address tomorrow. An-Na'im argues in his forthcoming book Decolonizing Human Rights ${ }^{50}$ that human rights, to be meaningful, let alone effective, must begin with people and what they believe and how they act in the world, not with the agendas of states or the imposed "norms" of the international community. I wish to make a kindred argument with regard to refugee policy. The idea of asylum recognizes that we humans share a pattern of movement from conditions of harm to conditions of safety. ${ }^{51}$ This pattern is not universal: when faced with harm some people choose to fight or to hide, but many flee, and they do so with consistency across time and geography.

${ }^{48}$ Harlan, "In an Immigration Court That Nearly Always Says No, a Lawyer's Spirit Is Broken."

49 Foley, "Here's Why Atlanta Is One of the Worst Places to Be an Undocumented Immigrant."

${ }^{50}$ Abdullahi Ahmed An-Na'im, Decolonizing Human Rights: From State-centric Enforcement to People-centered Practice (New York: Cambridge University Press, forthcoming); see also Abdullahi Ahmed An-Na'im, "Decolonizing Human Rights: An Urgent Plea for Rebuttal," (Memorial Lecture, Oxford University, July 27, 2017), https://scholarblogs.emory.edu/aannaim/ 2017/11/11/decolonizing-human-rights-an-urgent-plea-for-rebuttal-video/.

${ }^{51}$ For a more detailed analysis of this pattern of movement, see my 2013 article in Refuge. Silas W. Allard, "Reimagining Asylum: Religious Narratives and the Moral Obligation to the Asylum Seeker," Refuge: Canada's Journal on Refugees 29, no. 1 (2013), http://pi.library.yorku.ca/ojs/index.php/refuge/article/view/37521. 
Today, asylum adjudication begins with the question: Do you fit the confines of my "refugee box"? This question makes some frightened and desperate people into legal frauds. Instead, perhaps we should be asking: From what are you running? Perhaps we should be starting with a more open-ended question about what circumstances led this individual to make the difficult choice to flee across an international border. A human-centered refugee policy would be one that takes seriously people's impulse for preservation of self, family, and community, and thinks about the legal standards on those terms. ${ }^{52}$

This is not, yet, a legal argument. Such an approach may require new law, including new international treaties to address types of flight from harm that are not cognizable under the current Refugee Convention. ${ }^{53}$ Or, such an approach may require a new hermeneutic, building off of advances that have already been made in broadening the understanding of refugee to include those fleeing, for example, gender-based violence and persecution on the grounds of sexual orientation. ${ }^{54}$ As Schoenholtz has suggested, the Refugee Convention has proven flexible and able to evolve, at least in limited ways:

The State Parties created a treaty with two core and interlocking characteristics enabling this development: a special purpose that goes to the fundamental nature of the state system, and terms that possess a reasonable degree of flexibility. Recognizing these traits, lawyers have continuously adapted the refugee definition to new circumstances. ${ }^{55}$

It may be that we can interpret and adjudicate from a human-centered perspective, making the most of the Refugee Conventions flexibility. Whether it is a new legal framework or a new hermeneutic (or some combination of the two), a human-centered perspective is necessary to address what will be the ever-changing nature of displacement without continuing to empower exclusionary tendencies.

${ }^{52}$ To some extent this is already part of the philosophical conversation. See, for example, David Miller, Strangers in Our Midst: The Political Philosophy of Immigration (Cambridge, Massachusetts: Harvard University Press, 2016), chap. 5; Joseph Carens, The Ethics of Immigration (New York: Oxford University Press, 2013), chap. 10.

${ }^{53}$ See, for example, Betts, Survival Migration: Failed Governance and the Crisis of Displacement; see also Kevin Appleby, "Strengthening the Global Refugee Protection System: Recommendations for the Global Compact on Refugees," Journal on Migration and Human Security 5, no. 4 (2017): especially 783-85. There is currently work underway on a new "Global Compact on Responsibility Sharing on Refugees," and a "Global Compact for Safe, Orderly, and Regular Migration," but it is not clear that either compact will address the shortcomings of the Refugee Convention's definition. See Appleby, 783n5.

${ }^{54}$ Schoenholtz, "The New Refugees and the Old Treaty," 108-09.

${ }^{55}$ Schoenholtz, 119. 